\title{
Salinity and Sodicity Shock Quiona Plant Establishment
}

\author{
Muhammad Arshad Ullah'*, Muhammad Rasheed ${ }^{2}$, Imdad Ali Mahmood ${ }^{1}$, Badar uz Zaman ${ }^{1}$ and Syed Ishtiaq \\ Hyder $^{1}$
}

${ }^{1}$ Land Resources Research Institute, National Agricultural Research Centre, Pakistan

${ }^{2}$ Agronomy Department, University of Arid Agriculture, Rawalpindi, Pakistan

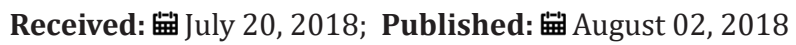

*Corresponding author: Muhammad Arshad Ullah, Land Resources Research Institute, National Agricultural Research Centre, Islamabad, Pakistan

\begin{abstract}
A possible alternative to minimize the effects of salt stress is the introduction of species tolerating these conditions with a good adaptability in terms of growth and yield. So, quinoa (Chenopodium quinoa Willd.) cultivar Titicaca was grown. In view of that a pot experiment was conducted to study the growth performance and ionic composition of Chenopodium quinoa. under saline - sodic conditions. Sixteen treatments i.e. $\left(\mathrm{T}_{1}=<4\left(\mathrm{dSm}^{-1}\right)+<15\left(\mathrm{mmolL}^{-1}\right)^{1 / 2}, \mathrm{~T}_{2}=20\left(\mathrm{dSm}^{-1}\right)+20\left(\mathrm{mmolL}^{-1}\right)^{1 / 2}, \mathrm{~T}_{3}=20\left(\mathrm{dSm}^{-1}\right)+40\left(\mathrm{mmolL}^{-1}\right)^{1 / 2}\right.$, $\mathrm{T} 4=20(\mathrm{dSm} 1)+60\left(\mathrm{mmolL}^{-1}\right)^{1 / 2}, \quad \mathrm{~T}_{5}=20\left(\mathrm{dSm}^{-1}\right)+80\left(\mathrm{mmolL}^{-1}\right)^{1 / 2}, \quad \mathrm{~T}_{6}=20\left(\mathrm{dSm}^{-1}\right)+100\left(\mathrm{mmolL}^{-1}\right)^{1 / 2}, \quad \mathrm{~T}_{7}=30(\mathrm{dSm} 1)+20\left(\mathrm{mmolL}^{-1}\right)^{1 / 2}$, $\mathrm{T}_{8}=30\left(\mathrm{dSm}^{-1}\right)+40\left(\mathrm{mmolL}^{-1}\right)^{1 / 2}, \quad \mathrm{~T}_{9}=30\left(\mathrm{dSm}^{-1}\right)+60\left(\mathrm{mmolL}^{-1}\right)^{1 / 2}, \quad \mathrm{~T}_{10}=30\left(\mathrm{dSm}^{-1}\right)+80\left(\mathrm{mmolL}^{-1}\right)^{1 / 2}, \quad \mathrm{~T}_{11}=30\left(\mathrm{dSm}^{-1}\right)+100\left(\mathrm{mmolL}^{-1}\right)^{1 / 2}$, $\mathrm{T}_{12}=40\left(\mathrm{dSm}^{-1}\right)+20\left(\mathrm{mmolL}^{-1}\right)^{1 / 2}, \mathrm{~T}_{13}=40\left(\mathrm{dSm}^{-1}\right)+40\left(\mathrm{mmol} \mathrm{L}^{-1}\right)^{1 / 2}, \mathrm{~T}_{14}=40\left(\mathrm{dSm}^{-1}\right)+60\left(\mathrm{mmol} \mathrm{L}^{-1}\right)^{1 / 2}, \mathrm{~T}_{15}=40\left(\mathrm{dSm}^{-1}\right)+80\left(\mathrm{mmol} \mathrm{L}^{-1}\right)^{1 / 2}$ and $\left.\mathrm{T}_{16}=40\left(\mathrm{dSm}^{-1}\right)+100\left(\mathrm{mmol} \mathrm{L}^{-1}\right)^{1 / 2}\right)$ were evaluated in order to investigate their effect on plant growth and yield. $\mathrm{T}_{1}$ attained the highest plant height $(80 \mathrm{~cm})$ due to having low saline sodic stress. Increased saline sodic stress decreased plant height $(44.7 \mathrm{~cm})$ and got the bottom position. \% decrease over control in plant height was also differed among treatments. This percentage was ranged from 1.25 to 44.12 due to variations in saline sodic stresses. The reduction in grain yield was addressed by the toxic effects of salts in saline sodic soils. $4.90 \%$ decrease over control in grain yield by $\mathrm{T}_{2}$ while $\mathrm{T}_{16}$ produced the increased \% decrease over control in grain yield (73.06). Similar trend was also observed in straw yield
\end{abstract}

Keywords: Salinity/Sodicity; Quinoa; Growth; Yield

\section{Introduction}

Salt affected area throughout the world is estimated at over 800 million hectares [1]. In Turkey, there is salinity problem in 1.5 million hectares of soils due to improper management of irrigation and inadequate drainage [2]. As a result of unsustainable and faulty agricultural practices, a considerable amount of agricultural land is put out of production each year. Increased salinization of arable land is expected to cause a land loss of $50 \%$ in 2050 [3]. Salinity and drought are two main environmental factors determining plant productivity and distribution of most major crops [4]. Soils are classified as saline when the electrical conductivity of a saturated paste (ECe) is $4 \mathrm{dS} \mathrm{m}^{-1}(40 \mathrm{mM} \mathrm{NaCl})$ or more [5]. So, over $6 \%$ of the global land area is affected by salt [6]. Salinity inhibits plant growth in two ways: first, it reduces the ability of plants to take up water (osmotic or water-deficit effect); second, excess salt in the transpiration stream causes injury to cells in the transpiring leaves (salt-specific or ion-excess effect). In the same context, Munns [7] confirmed that, plants respond to salinity stress in two phases: a rapid response to the increase in external osmotic pressure (starts immediately after the salt concentration around the roots increases to threshold levels, which decrease the new shoot growth) and a slower response due to the accumulation of $\mathrm{Na}^{+}$in leaves (salt accumulation to toxic concentrations and increase senescence of older leaves). Salinity is one of the significant problems commonly observed among irrigated agricultural lands. Nowadays it is showed that salinity soils affect between 20 and 50\% of irrigated arable lands worldwide [8]. Because of natural causes such as Irrigation water, soil structure, regional factors and some human activities, growth retardation and yield loss owing to salinity of soils is a common problem all over the world as most crop plants [7]. One option is the use of halophytic crop species, which can tolerate high levels of soil salinity. Many members of the family Chenopodiaceous are classified as salt tolerant one member of this family, quinoa (Chenopodium quinoa Willd) is able to grow on salinity soils [9]. 
The progressive salinization of irrigated land is a major environmental threat for crop production. Therefore, the selection and characterization of salt-resistant species are important to ensure future productivity of the arid and semi-arid agricultural regions [10] and it has garnered much attention around the world in recent years $[11,12]$. This interest based on not only its stress tolerance especially salinity soil condition, but also its nutritional quality especially high essential amino acid rates [13]. The main use of quinoa is for people such as cooking, baking, and various products for allergic to gluten and for animals such as feed, green fodder and for regulate plant growth with contains some phytohormones [14]. For these reasons, the year 2013 was declared "International Year of Quinoa" by the UN Food and Agriculture Organization (FAO) to focus attention on this crop worldwide [15]. Plants develop defense strategies against salt stress based on the activation of the ion transport system, osmotic adjustment and induction of antioxidant enzymes [16]. The capability of seedling establishment under saline conditions is dependent on cultivar [17]. Even though halophytic crop species are resistant against salinity levels into the soil, it has been shown in several studies that even halophytes are relatively sensitive to salinity during the stages of germination and seedling period [18]. Quinoa (Chenopodium quinoa Willd) has adapted to different agro-ecological zones range from sea level up to $4000 \mathrm{~m}$ altitude with its rich genetic diversity [19].

The United Nations Food and Agriculture Organization (FAO) declared 2013 as the "International Year of Quinoa" with the main objective to focus world attention on the role that quinoa's biodiversity and nutritional value play in food security [20]. Quinoa has been indicated as a good candidate to offer food security, especially in the face of the predicted future world scenario of increasing salinization and aridity [21]. In recent years, it has attracted interest all over the world and quinoa cultivation has begun expanding in many countries in Europe, Africa and Asia [22]. Quinoa is an annual herbaceous, dicotyledonous crop species belonging to the C3 group of plants [23]. It has been cultivated in the Andean region of Bolivia and Peru over a period of 5000 years $[24,25]$. The panicle consists in small flowers producing one seed per flower [26]. Seed color varies from white, yellow, red to black depending on cultivars. The 1000 grain mass is generally low (3$6 \mathrm{~g}$ ) due to the small seeds [27]. At the same time, quinoa is well adapted to grow under unfavorable soil and climatic conditions [19]. It has been cultivated on various types of soils including quite poor, saline or inadequately drained marginal soils with a wide pH range from 4.8 to 8.5 in Bolivian salt flats [28]. Quinoa shows exceptional adaptation to harsh environments such as drought and salinity [29]. Soil salinity reduces crop yields and is a worldwide problem. In the United States, approximately 2.2 million hectares of cropland in 48 States were occupied by saline soils, while another 30.8 million hectares are at risk of becoming saline (United States Department of Agriculture) [5]. Drought and salinity are common adverse environmental factors that affect the growth of plants and are considered as the main factors determining the global geographic distribution of vegetation and restriction of crop yields in agriculture [30,31].

Desertification and salinization are rapidly increasing on a global scale declining average yields for most major crop plants by more than $50 \%$ [32]. Chenopodium spp. have been cultivated for centuries as a leafy vegetable (Chenopodium album) as well as an important subsidiary grain crop (Chenopodium quinoa and C. album) for human and animal food stuff due to high-protein and essential amino acids [33], a wide range of vitamins $\left(A, B_{2}, E\right)$ and minerals (Ca, $\mathrm{Fe}, \mathrm{Cu}, \mathrm{Mg}, \mathrm{Zn}$ ) [13]. Although, quinoa grains do not contain gluten and thus, they cannot be used alone for bread- making. However, they can be mixed with wheat flour in the preparation of bread with high nutritional value [34]. Accordingly, quinoa has been selected by the food and agriculture organization (FAO) as one of the crops destined to offer food security in the 21st century [11]. Several studies showed that even halophytes are particularly salt sensitive during the stages of seed germination and seedling establishment $[35,36]$. However, they have an advantage over plant species that lack strategies to deal with salt in the soil [37]. Salinity tolerance is a heritable trait with a polygenic character linked to a complex genetic basis that can be used as an efficient criterion for selection of salt resistant populations [38]. There is also evidence to support the view that salt tolerance is a complex physiological trait affecting entirely the plant's life [39]. In addition, the quinoa plant is reported to be tolerant to drought [40], and also resists frost before the flower-bud formation stage [41] and salinity $[17,42]$.

However, the definition of indicators that plant breeders might apply in open field to improve quinoa, for its tolerance or adjustment to saline environments, is still a matter of debate [43]. Quinoa a grain crop belongs to Amaranthaceae family with superior nutritional profile, originated from Andean region of Latin America where its cultivation was found seven thousand years ago [11]. The interest about this crop is increasing over the world, both due to abiotic stress tolerance and superior nutritional benefits [44]. Grain of quinoa is gluten-free, contain substantial amount of all essentialamino acid, vitamins, (A, B2 and E), minerals ( $\mathrm{Ca}, \mathrm{K}, \mathrm{Fe}, \mathrm{Mn}$ ) and health supportive fatty-acids (omega 3) [13]. Recently in Pakistan quinoa has been successfully introduced, cultivated and basic production technology developed [45]. This traditional Andean seed crop has been cultivated in the Peruvian and Bolivian Andes [46] and the crop is rapidly gaining interest throughout the world [24]. Quinoa is well adapted to grow under unfavorable soil and climatic conditions [19]. Quinoa is a halophytic species emerging as a potential new crop in many regions of the world because of the nutritional composition of their seeds $[13,24,47]$. It has all the essential amino acids for human life and in quantities close to the necessary equilibrium [48]. 
Its balanced composition makes the protein quality of quinoa comparable to that of mother milk $[49,50]$. Despite the high nutritional value of the seeds, they also contain in the pericarp the anti-nutritious component, saponin, in a certain concentration depending mainly on the variety (Ward, 2000) and on the stress conditions of the plant [51]. Protein content in most quinoa accessions has been reported to range from 12 to $17 \%$, depending on variety, environment, and inputs [52]. This range tends to be higher than the protein content of wheat, barley, and rice, which were reported to be $10.5-14 \%, 8-14 \%$, and $6-7 \%$, respectively $[53,54]$. Additionally, quinoa has a well-balanced complement of essential amino acids. Specifically, quinoa is rich in lysine, which is considered the first limiting essential amino acid in cereals [55]. Furthermore, with a lack of gluten protein, quinoa can be safely consumed by gluten sensitive/intolerant population [56]. The aim of the study was to evaluate the salt tolerance potential of newly introduced quiona (Chenopodium quinoa Willd), against combined salinity and sodicity stresses.

\section{Materials and Methods}

A pot study was conducted to evaluate the growth and yield of (Chenopodium quinoa Willd.) under different artificial developed saline- sodic soils at green house of Land Resources Research Institute, National Agricultural Research Centre, Islamabad, Pakistan during, 27 $7^{\text {th }}$ November 2017 to April 2018. The soil used for the pot experiment was analysed and having $7.99 \mathrm{pH}_{\mathrm{s}} 1.32 \mathrm{ECe}$ $\left(\mathrm{dSm}^{-1}\right)$, 3.88 SAR $\left(\mathrm{mmol} \mathrm{L}^{-1}\right)^{1 / 2}, 29.01$ Saturation Percentage (\%), 0.42 O.M. (\%), 7.89 Available P (mg $\mathrm{Kg}^{-1}$ ) and 106.32 Extractable $\mathrm{K}\left(\mathrm{mg} \mathrm{Kg}^{-1}\right)$. Considering the pre- sowing soil analysis, the ECe (Electrical conductivity) and SAR (Sodium Absorption Ratio) was artificially developed with salts of $\mathrm{NaCl}, \mathrm{Na}_{2} \mathrm{SO}_{4}, \mathrm{CaCl}_{2}$ and $\mathrm{MgSO}_{4}$ using Quadratic Equation.10 Kg soil was used to fill each pot. 10 seeds of Chenopodium quinoa Willd were sown in each pot. Fertilizer was applied @75-60-50 NPK Kg ha-1 NPK Kg ha1. Treatments were as $\mathrm{T}_{1}=<3.66\left(\mathrm{dSm}^{-1}\right)+<13.85\left(\mathrm{mmolL}^{-1}\right)^{1 / 2}$, $\mathrm{T}_{2}=5\left(\mathrm{dSm}^{-1}\right)+25\left(\mathrm{mmol}^{-1}\right)^{1 / 2}, \quad \mathrm{~T}_{3}=10\left(\mathrm{dSm}^{-1}\right)+25\left(\mathrm{mmolL}^{-1}\right)^{1 / 2}$, $\mathrm{T}_{4}=15\left(\mathrm{dSm}^{-1}\right)+25\left(\mathrm{mmol} \mathrm{L}^{-1}\right)^{1 / 2}, \quad \mathrm{~T}_{5}=20\left(\mathrm{dSm}^{-1}\right)+25 \quad\left(\mathrm{mmolL}^{-1}\right)^{1 / 2}$,
$\mathrm{T}_{6}=25\left(\mathrm{dSm}^{-1}\right)+25\left(\mathrm{mmolL}^{-1}\right)^{1 / 2}, \quad \mathrm{~T}_{7}=5\left(\mathrm{dSm}^{-1}\right)+30\left(\mathrm{mmol}^{-1}\right)^{1 / 2}$, $\mathrm{T}_{8}=10\left(\mathrm{dSm}^{-1}\right)+30\left(\mathrm{mmol} \mathrm{L}^{-1}\right)^{1 / 2}, \mathrm{~T}_{9}=15\left(\mathrm{dSm}^{-1}\right)+30\left(\mathrm{mmol} \mathrm{L}^{-1}\right)^{1 / 2}$, $\mathrm{T}_{10}=20\left(\mathrm{dSm}^{-1}\right)+30\left(\mathrm{mmol} \mathrm{L}^{-1}\right)^{1 / 2}, \quad \mathrm{~T}_{11}=25\left(\mathrm{dSm}^{-1}\right)+30\left(\mathrm{mmol} \mathrm{L}^{-1}\right)^{1 / 2}$, $\mathrm{T}_{12}=5\left(\mathrm{dSm}^{-1}\right)+40\left(\mathrm{mmol} \mathrm{L}^{-1}\right)^{1 / 2}, \mathrm{~T}_{13}=10\left(\mathrm{dSm}^{-1}\right)+40\left(\mathrm{mmol} \mathrm{L}^{-1}\right)^{1 / 2}, \mathrm{~T}_{14}=$ $15\left(\mathrm{dSm}^{-1}\right)+40\left(\mathrm{mmol} \mathrm{L}^{-1}\right)^{1 / 2}, \mathrm{~T}_{15}=20\left(\mathrm{dSm}^{-1}\right)+40\left(\mathrm{mmol} \mathrm{L}^{-1}\right)^{1 / 2}$ and $\mathrm{T}_{16=} 25\left(\mathrm{dSm}^{-1}\right)+40\left(\mathrm{mmol} \mathrm{L}^{-1}\right)^{1 / 2}$. Completely randomized deign was applied with three repeats. Data on biomass and grain yield were collected. The data obtained were subjected to statistical analysis using the STATISTIX statistical software (Version 8.1) and the mean values were compared using least significant difference (LSD) (Steel and Torrie, 1997).

\section{Results and Discussion}

Human food is the main issue in the world as well as Pakistan for the huge population. Therefore, we have to work for the economical utilization of salt- affected lands to meet the food requirements of Pakistani habitats. Bio- saline agriculture is the technique to use the salt affected lands without chemical amendments. Sat tolerant plants serve this issue economically as well as friendly environmentally. Therefore, Quiona plant was studied under different artificially developed saline sodic soils. Plant height was significantly affected with salinity and sodicity stresses (Table-1). $\mathrm{T}_{1}$ attained the highest plant height $(80 \mathrm{~cm})$ due to having low saline sodic stress. Increased saline sodic stress decreased plant height $(44.7 \mathrm{~cm})$ and got the bottom position. \% decrease over control in plant height was also differed among treatments. This percentage was ranged from 1.25 to 44.12 due to variations in saline sodic stresses. Quinoa's robust character is because of a high tolerance level of soil salinity $[11,41,56,57]$. Quinoa displays optimum growth in range of 100 to $200 \mathrm{mM} \mathrm{NaCl}$, that why considered as true halophyte. Moreover, some genotypes can tolerate and grow with salt concentrations of seawater $\left(40 \mathrm{dSm}^{-1}\right)[11,58]$. Total biomass data presented in Table 1 showed statistically significant results. The highest total biomass pot $^{-1}(489 \mathrm{~g})$ was attained by control i.e. $\mathrm{T}_{1}$. Lowest total biomass pot $^{-1}(154.5 \mathrm{~g})$ was attained by $\mathrm{T}_{11}[25(\mathrm{dSm}$ $\left.\left.{ }^{1}\right)+30\left(\mathrm{mmol} \mathrm{L}^{-1}\right)^{1 / 2}\right]$. \% decrease over control in total biomass pot ${ }^{1}$ was the bottom (2.35g) at $\mathrm{T}_{2}$ while the top ranked by $\mathrm{T}_{16}$ (76.62). Quiona.

\begin{tabular}{|c|c|c|c|c|c|c|c|c|}
\hline Treatment & $\begin{array}{c}\text { Plant } \\
\text { Height }(\mathbf{c m})\end{array}$ & $\begin{array}{c}\text { \% decrease } \\
\text { over control }\end{array}$ & $\begin{array}{c}\text { Total Biomass } \\
\text { pot- }^{-1} \mathbf{( g )}\end{array}$ & $\begin{array}{c}\text { \% decrease } \\
\text { over control }\end{array}$ & $\begin{array}{c}\text { Grain Yield } \\
\text { (g) }\end{array}$ & $\begin{array}{c}\text { \% decrease } \\
\text { over control }\end{array}$ & $\begin{array}{c}\text { Straw Yield } \\
\text { (g) }\end{array}$ & $\begin{array}{c}\text { \% decrease } \\
\text { over control }\end{array}$ \\
\hline $\mathrm{T}_{1}$ & $80.0 \mathrm{a}$ & --- & $489.0 \mathrm{a}$ & ---- & $98.0 \mathrm{a}$ & ------ & $388.0 \mathrm{a}$ & ------- \\
\hline $\mathrm{T}_{2}$ & $79.0 \mathrm{ab}$ & 1.25 & $477.5 \mathrm{ab}$ & 2.35 & 93.2 & 4.9 & $366.6 \mathrm{abc}$ & 5.51 \\
\hline $\mathrm{T}_{3}$ & $77.5 \mathrm{abc}$ & 3.12 & $450.0 \mathrm{bc}$ & 9.2 & $89.5 \mathrm{abc}$ & 8.67 & $360.0 \mathrm{bc}$ & 7.22 \\
\hline $\mathrm{T}_{4}$ & $73.0 \mathrm{abc}$ & 8.75 & $432.0 \mathrm{~cd}$ & 11.66 & $86.0 \mathrm{bc}$ & 12.24 & $345.0 \mathrm{~cd}$ & 11.08 \\
\hline $\mathrm{T}_{5}$ & $63.5 \mathrm{e}$ & 20.62 & $360.0 \mathrm{e}$ & 26.38 & $63.4 \mathrm{~d}$ & 35.31 & $246.5 \mathrm{e}$ & 36.47 \\
\hline $\mathrm{T}_{6}$ & $54.0 \mathrm{fg}$ & 32.5 & $176.0 \mathrm{~g}$ & 64.01 & $37.0 \mathrm{f}$ & 62.24 & $135.0 \mathrm{~g}$ & 65.21 \\
\hline $\mathrm{T}_{7}$ & $76.0 \mathrm{abc}$ & 5 & $470.1 \mathrm{ab}$ & 3.86 & $90.5 \mathrm{abc}$ & 7.65 & $360.0 \mathrm{ab}$ & 7.21 \\
\hline $\mathrm{T}_{8}$ & $72.5 \mathrm{bcd}$ & 9.37 & $443.9 \mathrm{bc}$ & 9.22 & $87.0 \mathrm{bc}$ & 11.22 & $356.0 \mathrm{bc}$ & 8.25 \\
\hline $\mathrm{T}_{9}$ & $64.5 \mathrm{de}$ & 19.37 & $410.0 \mathrm{~d}$ & 16.15 & $83.5 \mathrm{c}$ & 14.79 & $325.0 \mathrm{~d}$ & 16.24 \\
\hline
\end{tabular}




\begin{tabular}{|c|c|c|c|c|c|c|c|c|}
\hline $\mathrm{T}_{10}$ & $58.0 \mathrm{f}$ & 27.5 & $272.0 \mathrm{f}$ & 44.38 & $52.0 \mathrm{de}$ & 46.94 & $218.0 \mathrm{f}$ & 43.81 \\
\hline $\mathrm{T}_{11}$ & $55.0 \mathrm{fg}$ & 31.25 & $154.5 \mathrm{~g}$ & 68.4 & $30.4 \mathrm{fg}$ & 68.98 & $120.0 \mathrm{~g}$ & 69.07 \\
\hline $\mathrm{T}_{12}$ & $79.0 \mathrm{abc}$ & 1.25 & $472.5 \mathrm{ab}$ & 3.37 & $90.2 \mathrm{a}$ & 7.95 & $376.0 \mathrm{ab}$ & 3.09 \\
\hline $\mathrm{T}_{13}$ & $74.5 \mathrm{~cd}$ & 6.87 & $450.1 \mathrm{bc}$ & 7.95 & $86.2 \mathrm{bc}$ & 12.04 & $360.0 \mathrm{bc}$ & 7.21 \\
\hline $\mathrm{T}_{14}$ & $66.6 \mathrm{e}$ & 16.75 & $250.1 \mathrm{f}$ & 48.85 & $51.0 \mathrm{e}$ & 47.95 & $207.5 \mathrm{f}$ & 46.52 \\
\hline $\mathrm{T}_{15}$ & $49.9 \mathrm{gh}$ & 37.62 & $179.1 \mathrm{~g}$ & 63.37 & $38.6 \mathrm{f}$ & 39.39 & $145.5 \mathrm{~g}$ & 62.5 \\
\hline $\mathrm{T}_{16}$ & $44.7 \mathrm{~h}$ & 44.12 & $114.3 \mathrm{~h}$ & 76.62 & $26.4 \mathrm{~g}$ & 73.06 & $86.9 \mathrm{~h}$ & 77.6 \\
\hline & 7.22 & ----- & 33.1 & ----- & 8.28 & $-\cdots---$ & 24.55 & $-\cdots$ \\
\hline
\end{tabular}

$\left.\mathrm{T}_{1}=<3.66\left(\mathrm{dSm}^{-1}\right)+<13.85\left(\mathrm{mmol} \mathrm{L}^{-1}\right)^{1 / 2}, \mathrm{~T}_{2}=5\left(\mathrm{dSm}^{-1}\right)+25\left(\mathrm{mmol} \mathrm{L}^{-1}\right)^{1 / 2}, \mathrm{~T}_{3}=10\left(\mathrm{dSm}^{-1}\right)+25\left(\mathrm{mmol} \mathrm{L}^{-1}\right)^{1 / 2}, \mathrm{~T}_{4}=15(\mathrm{dSm})^{-1}\right)+25\left(\mathrm{mmol} \mathrm{L}^{-1}\right)^{1 / 2}$, $\mathrm{T}_{5}=20\left(\mathrm{dSm}^{-1}\right)+25\left(\mathrm{mmol} \mathrm{L}^{-1}\right)^{1 / 2}, \mathrm{~T}_{6}=25\left(\mathrm{dSm}^{-1}\right)+25\left(\mathrm{mmol} \mathrm{L}^{-1}\right)^{1 / 2}, \mathrm{~T}_{7}=5\left(\mathrm{dSm}^{-1}\right)+30\left(\mathrm{mmol} \mathrm{L}^{-1}\right)^{1 / 2}, \mathrm{~T}_{8}=10\left(\mathrm{dSm}^{-1}\right)+30\left(\mathrm{mmol} \mathrm{L}^{-1}\right)^{1 / 2}, \mathrm{~T}_{9}=15\left(\mathrm{dSm}^{-}\right.$ $\left.{ }^{1}\right)+30\left(\mathrm{mmol} \mathrm{L}^{-1}\right)^{1 / 2}, \quad \mathrm{~T}_{10}=20\left(\mathrm{dSm}^{-1}\right)+30\left(\mathrm{mmol} \mathrm{L}^{-1}\right)^{1 / 2}, \quad \mathrm{~T}_{11}=25\left(\mathrm{dSm}^{-1}\right)+30\left(\mathrm{mmol} \mathrm{L}^{-1}\right) 1 / 2, \mathrm{~T}_{12}=5\left(\mathrm{dSm}^{-1}\right)+40\left(\mathrm{mmol}^{-1}\right)^{1 / 2}, \mathrm{~T}_{13}=10\left(\mathrm{dSm}^{-}\right.$ $\left.{ }^{1}\right)+40\left(\mathrm{mmol} \mathrm{L}^{-1}\right)^{1 / 2}, \mathrm{~T}_{14}=15\left(\mathrm{dSm}^{-1}\right)+40\left(\mathrm{mmol} \mathrm{L}^{-1}\right) 1 / 2, \mathrm{~T}_{15}=20\left(\mathrm{dSm}^{-1}\right)+40\left(\mathrm{mmol} \mathrm{L}^{-1}\right)^{1 / 2}$ and $\mathrm{T}_{16}=25\left(\mathrm{dSm}^{-1}\right)+40\left(\mathrm{mmol} \mathrm{L}^{-1}\right)^{1 / 2}$.

This variation indicated the severe impact of salinity and sodicity in growth of quiona plant. The conditions for crop growth are very difficult in the high region of the Andes, where the most harmful a biotic adverse factor that affect crop production are drought, frost, soil salinity, hail, snow, wind, flooding, and heat [19]. Quinoa can be successfully grown on marginal soils [11] which were the main objective to introduce in Pakistan has yet to be tested under local salt -affected conditions. Significant variations exist among quinoa accessions for physiological and agronomical variables when raised under different set of saline conditions [58]. Data regarding grain yield performed significant differences as indicated in Table 1. The worst impact of saline and sodic soil stresses showed the lowest result (26.4g) in $\mathrm{T}_{16}$, However, $\mathrm{T}_{1}$ i.e. control gained the highest grain yield (98g). This reduction in grain yield was addressed by the toxic effects of salts in saline sodic soils. $4.90 \%$ decrease over control in grain yield by $\mathrm{T}_{2}$ while $\mathrm{T}_{16}$ produced the increased $\%$ decrease over control in grain yield (73.06). Similar trend was also observed in straw yield as presented in Table 1. The salinity issue leads producers to grow more salt-tolerant crops, such as quinoa Many studies have focused on quinoa' salt tolerance to soil salinity, with a particular emphasis on plant physiology [10,58-65] and agronomic characteristics such as germination rate, plant height, and yield [66-75].

\section{References}

1. Rengasamy P (2010) Soil processes affecting crop production in salt affected soils. Functional Plant Biology 37: 613-620.

2. FAO (2014) Irrigation in the Middle East region in figures-AQUASTAT Survey 2008.

3. Wang WX, Vinocur B, Altman A (2003) Plant responses to drought, salinity and extreme temperatures: towards genetic engineering for stress tolerance. Planta 218(1): 1-14.

4. Bartels D, Sunkar R (2005) Drought and salt tolerance in plants. Crit Rev Plant Sci 24: 23-58.

5. USDA ARS (2008) Research databases Bibliography on salt tolerance. Riverside, CA: US Dep. Agric, Agric Res Serv, US Salinity Lab.

6. Munns R (2005) Genes and salt tolerance: bringing them together. New Phytol 167: 645-63.
7. Munns R, M Tester (2008) Mechanisms of salinity tolerance. Annu Rev Plant Biol 59: 651-681

8. Pitman MG, Läuchli A (2002) Global impact of salinity and agricultural ecosystems Salinity: environment plants molecules. 3: 20.

9. Wilson C, Read JJ, Abo Kassem E (2002) Effect of mixed-salt salinity on growth and ion relations of a quinoa and a wheat variety. Journal of Plant Nutrition 25(12): 2689-2704.

10. Ruiz Carrasco K, Antognoni F, Coulibaly AK, Lizardi S, Covarrubias A et al. (2011) As assessed by growth, physiological traits, and sodium transporter gene expression. Plant Physiol Biochem 49 (11):1333-1341.

11. Jacobsen SE (2003) The Worldwide Potential for Quinoa (Chenopodium quinoa Willd) Food Rev Int 19. 167-177.

12. Jacobsen SE, Mujica A, Jensen CR (2003) The resistance of quinoa (Chenopodium quinoa Willd) to adverse abiotic factors. Food Reviews International 19 (1-2): 99-109.

13. Repo Carrasco R, Espinoza C, Jacobsen SE (2003) Nutritional value and use of the Andean crops quinoa (Chenopodium quinoa) and kañiwa (Chenopodium pallidicaule) Food reviews international 19(1-2): 179189.

14. James JJ, Alder NN, Mühling KH, Läuchli AE, Shackel KA et al. (2005) High apoplastic solute concentrations in leaves alter water relations of the halophytic shrub, Sarcobatus vermiculatus. Journal of Experimental Botany, 57(1): 139-147.

15. Small E (2013) Quinoa: is the United Nations featured crop of 2013 bad for biodiversity. Biodiversity 14(3): 169-179.

16. Flagella Z, Trono D, Pompa M, Di Fonzo N, Pastore D (2006) Seawater stress applied at germination affects mitochondrial function in durum wheat (Triticum durum) early seedlings. Functional Plant Biology, 33(4): 357-366.

17. Hariadi Y, K Marandon, Y Tian, SE Jacobsen, S Shabala (2011) Ionic and osmotic relations in quinoa (Chenopodium quinoa Willd.) plants grown at various salinity levels. J Exp Bot 62(1):185-193.

18. Debez A, Saadaoui D, Ramani B, Ouerghi Z, Koyro HW et al. (2006) Leaf $\mathrm{H}^{+}$-ATPase activity and photosynthetic capacity of Cakile maritima under increasing salinity. Environmental and Experimental Botany 57(3): 285-295.

19. Garcia M, Raes D, Jacobsen SE (2003) Evapotranspiration analysis and irrigation requirements of quinoa (Chenopodium quinoa Willd) in the Bolivivan highlands. Agricultural Water Management 60(2): 119- 134.

20. FAO (2011) Quinoa: An ancient crop to contribute to world food security. FAO Regional Office for Latin America and the Caribbean.

21. Ruiz KB, Biondi S, Oses R, Acuña Rodríguez IS., Antognoni, F et al. (2014) Quinoa biodiversity and sustainability for food security under climate 
change. A review. Agronomy for Sustainable Development 34 (2): 349359.

22. FAO (2013) Food outlook biannual report on global food markets.

23. Jacobsen SE (2003) The worldwide potential for quinoa (Chenopodium quinoa Willd) Food Reviews International 19: 167-177.

24. Bhargava A, Shukla S, Ohri D (2006) Chenopodium quinoa-an Indian perspective. Industrial Crops and Products 23(1): 73-87.

25. Vega Galvez A, Miranda M, Vergara J, Uribe E, Puente L, et al. (2010) Nutrition facts and functional potential of quinoa (Chenopodium quinoa Willd.), an ancient Andean grain: a review. Journal of the Science of Food and Agriculture 90(15): 2541-2547.

26. Geerts S, Raes D, Garcia M, Condori O, Mamani J et al. (2008a) Could deficit irrigation be a sustainable practice for quinoa (Chenopodium quinoa Willd.) in the Southern Bolivian Altiplano? Agricultural Water Management 95(8): 909-917.

27. Geerts S, Raes D, Garcia M, Vacher J, Mamani R et al. (2008b) Introducing deficit irrigation to stabilize yields of quinoa (Chenopodium quinoa Willd). European Journal of Agronomy 28(3): 427- 436.

28. Bosque Sanchez H, Lemeur R, Van Damme P, Jacobsen SE (2003) Ecophysiological analysis of drought and salinity stress of quinoa (Chenopodium quinoa Willd.). Food Reviews International 19: 111-119.

29. González JA, Eisa SSS, Hussin SAES, and Prado FE (2015) Quinoa: an Incan crop to face global changes in agriculture, in Quinoa: Improvement and Sustainable Production, eds KM Murphy and J Matanguihan (Hoboken NJ: John Wiley \& Sons). pp. 7-11.

30. Gregory PJ (2006) Food production under poor, adverse climatic conditions. In Proc IX ESA Congress Warsaw Poland pp. 19.

31. Lin KH, PY Chao, CM Yang, WC Cheng, HF Lo et al. (2006) The effects of flooding and drought stresses on the antioxidant constituents in sweet potato leaves. Bot Stud 47:417- 426.

32. Bray EA, J Bailey Serres, E Weretilnyk (2000) Responses to abiotic stresses In W Gruissem, B Buchnnan, and R Jones, eds Biochemistry and Molecular Biology of Plants. American Society of Plant Physiologists, Rockville, USA, pp. 1158-1249.

33. Bhargava A, Shukla S, Ohri D (2003a) Genetic variability and heritability of selected traits during different cuttings of vegetable Chenopodium. Ind J Genet Plant Breed 63(4): 359-360.

34. Morita N, Hirata C, Park SH, Mitsunaga T (2001) Quinoa flour as a new food stuff for improving dough and bread. J Appl Glyco Sci 48(3): 263270.

35. Tobe K, Li X, Omasa K (2000) Seed germination and radicle growth of a halophyte, Kalidium capsicum (Chenopodiaceae). Ann Bot 85(3): 391396.

36. Malcolm CV, Lindley VA, O Leary, JW Runciman, HV Barrett et al. (2003) Halophyte and glycophyte salt tolerance at germination and the establishment of halophyte shrubs in saline environments. Plant Soil 253 (1): 171-185.

37. Rosa M, Hilal M, González JA, Prado FE (2004) Changes in soluble carbohydrates and related enzymes induced by low temperature during early developmental stages of quinoa (Chenopodium quinoa) seedlings. J Plant Physio 161(6): 683-689.

38. Flowers T], Colmer TD (2008) Salinity tolerance in halophytes. New Phytol 179(4): 945-963.

39. Flowers TJ (2004) Improving crop salt tolerance. J Exp Bot 55(396): 307-319.

40. Garcia M, Raes D, Jacobsen SE, Michel T (2007) Agroclimatic contraints for rainfed agriculture in the Bolivian Altiplano. J Arid Environ 71(1): 109-121.
41. Jacobsen SEC, Monteros JL, Christiansen LA, Bravo LJ, Corcuera et al. (2005) Plant responses of quinoa (Chenopodium quinoa Willd) to frost at various phenological stages. Eur J Agron 22 (2):131-139.

42. Ruffino AMC, M Rosa, M Hilal, JA González, FE Prado (2010) The role of cotyledon metabolism in the establishment of quinoa (Chenopodium quinoa) seedlings growing under salinity. Plant Soil 326 (1-2): 213-224

43. Razzaghi F, Ahmadi SH, Adolf SH, Jensen CR, Jacobsen SE et al. (2011a) Water relations and transpiration of quinoa (Chenopodium quinoa Willd) under salinity and soil drying. J Agr Crop Sci 197: 348-360.

44. Stikic R, D Glamoclija, M Demin, B Vucelic Radovic, Z Jovanovic, et al. (2012) Agronomical and nutritional evaluation of quinoa seeds (Chenopodium quinoa Willd.) as an ingredient in bread formulations. J Cereal Sci 55(2): 132-138.

45. Basra SMA, S Iqbal, I Afzal (2014) Evaluating the response of nitrogen application on growth, development and yield of quinoa genotypes. Int J Agric Biol 16(5): 886-892.

46. Jacobsen SE (2011) The situation for quinoa and its production in Southern Bolivia from economic success to environmental disaster. J Agron Crop Sci 197(5): 390-399.

47. Jacobsen SEC, Monteros LJ, Corcuera LA, Bravo JL, Christiansen (2007) Frost resistance mechanisms in quinoa (Chenopodium quinoa Willd) Eur J Agron 26: 471-475.

48. Dini I, GC Tenore, A Dini (2005) Nutritional and antinutritional composition of Kancolla seeds: an interesting and underexploited Andine food plant. Food Chem 92(1): 125-132.

49. Collao Perez FR (2001) The productive chain of quinoa in Bolivia. World Bank Report, La Paz, Bolivia. Comai S, A Bertazzo, L Bailoni, M Zancato, CVL Costa, G Allegri 2007: The content of proteic and non proteic (free and protein-bound) tryptophan in quinoa and cereal flours. Food Chem 100: $1350-1355$.

50. Rojas W, JL Soto, E Carrasco (2004) Study on the Social Environmental and Economic Impacts of Quinoa Promotion in Bolivia PROINPA Foundation. La Paz Bolivia.

51. Szakiel A, C Paczkowski, M Henry (2010) Influence of Environmental a Biotic Factors on the Content of Saponinin Plants. Phytochem Rev.

52. Rojas W, Pinto M, Alanoca C, Pando LG, Leónlobos P et al. (2011) Chapter1.5: Quinoa genetic resources and exsitu conservation. pp. 5682.

53. Shih F (2006) Chapter6: Rice protein, in Rice: Chemistry and Technology, $3^{\text {th }}$ Edn, E.T. Champagne (St. Paul, MN: American Association of Cereal Chemists, Inc.), pp. 143-144.

54. Cai S, Yu G, Chen X, Huang Y, Jiang X, Zhang G (2013) Grain protein content variation and its association analysis in barley. BMC Plant Boil 13: 35 .

55. Taylor JRN, Parker ML (2002) Chapter3: Quinoa in Pseudo cereals and Less Common Cereals: Grain Properties and Utilization Potential, eds P Belton and J Taylor (Berlin: Springer Science and Business Media). pp. 100-101.

56. Zevallos VF, Herencia LI, Chang F, Donnelly S, Ellis HJ, et al. (2014) Gastrointestinal effects of eating quinoa (Chenopodium quinoa Willd.) in celiac patients. Am J Gastroenterol 109(2): 270-278.

57. Razzaghi FSH, Ahmadi VI, Adolf CR, Jensen SE, Jacobsen, et al. (2011) Water relations and transpiration of quinoa (Chenopodium quinoa Willd) under salinity and soil drying. J Agron Crop Sci 197: 348-360.

58. Adolf VI, S Shabala, MN Andersen, F Razzaghi, SE Jacobsen (2012) Varietal differences of quinoa's tolerance to saline conditions. Plant Soil 357: 117-129.

59. Cocozza C, Pulvento C, Lavini A, Riccardi M, d Andria R et al. (2013) Effects of increasing salinity stress and decreasing water availability on 
ecophysiological traits of quinoa (Chenopodium quinoa Willd.) grown in a Mediterranean type agroecosystem. J Agron CropSci 199: 229-240.

60. Shabala S,Hariadi Y, Jacobsen SE (2013) Genotypic difference in salinity tolerance in quinoa is determined by differential control of xylem $\mathrm{Na}(+)$ loading and stomatal density. J PlantPhysiol 170(10): 906-914.

61. Prado FE, Boero C, Gallardo M, González JA (2000) Effect of $\mathrm{NaCl}$ on germination, growth, and soluble sugar content in Chenopodium quinoa Willd seeds Bot Bull Acad Sinica 41: 27-34.

62. Chilo G, Molina MV, Carabajal R, Ochoa M (2009) Temperature and salinity effects on germination and seedling growth on two varieties of Chenopodium quinoa. Agri-Scientia 26(1): 15-22.

63. Razzaghi F, Ahmadi SH, Jacobsen SE, Jensen CR, ersen MN (2012) Effects of salinity and soil drying on radiation use efficiency, water productivity and yield of quinoa (Chenopodium quinoa Willd) J Agron Crop Sci 198(3): 173-184.

64. Peterson AJ (2013) Salinity Tolerance and Nitrogen Use Efficiency of Quinona or Expande Production in Temperate North America. PhD Thesis, Washington State University, Pullman

65. Peterson A, Murphy K (2015) Tolerance of low land quinoa cultivars to sodium chloride and sodium sulfate salinity. Crop Sci 55: 331-338.

66. Akhtar J, ZA Saqib, M Sarfraz, I Saleem, MA Haq (2010) Evaluating salt tolerant cotton genotypes at different levels of $\mathrm{NaCl}$ stress in solution and soil culture. Pak J Bot 42(4): 2857-2866.

67. Azevedo N, JT Prisco, J EneasFilho, CEB Abreu, EG Filho (2006) Effect of salt stress on antioxidative enzymes and lipid peroxidation in leaves and roots of salt-tolerant and salt-sensitive maize genotypes. Env Expt Bot 56(1): 87-94.

68.

69. Blumwald EA, Grover, G Allen (2004) Breeding for abiotic stress resistance: challenges and opportunities. In: Proceedings of the $4^{\text {th }}$ International Crop Science Congress, 26 Sep-1 Oct 2004. Brisbane, Australia.

70. Pattanagul WT, Maysaya (2008) Effect of salinity stress on growth and carbohydrate metabolism in three rice (Oryza sativa L) cultivars differing in salinity tolerance. Ind J Exp Biol 46 (10): 736-742

71. Schleiff U (2008) Analysis of water supply of plants under saline soil conditions and conclusions for research on crop salt tolerance. J Agron Crop Sci 194(1): 1-8.

72. Shabala S, A Mackay (2011) Ion transport in halophytes. Adv Bot Res 57: 151-199.

73. Shabala S, TA Cuin (2008) Potassium transport and plant salt tolerance. Physiol Plant 133(4): 651-669.

74. Shahbaz M, M Ashraf (2013) Improving salinity tolerance in cereals. Crit Rev Plant Sci 32(4): 237-249.

75. Yilmaz K, IE Akinci, S Akinci (2004) Effect of salt stress on growth and $\mathrm{Na}, \mathrm{K}$ contents of pepper (Capsicum annuum L.) in germination and seedling stages. Pak J Biol Sci 7(4): 606-610.

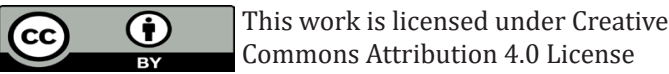

To Submit Your Article Click Here: Submit Article

DOI: $10.32474 /$ CIACR.2018.04.000179

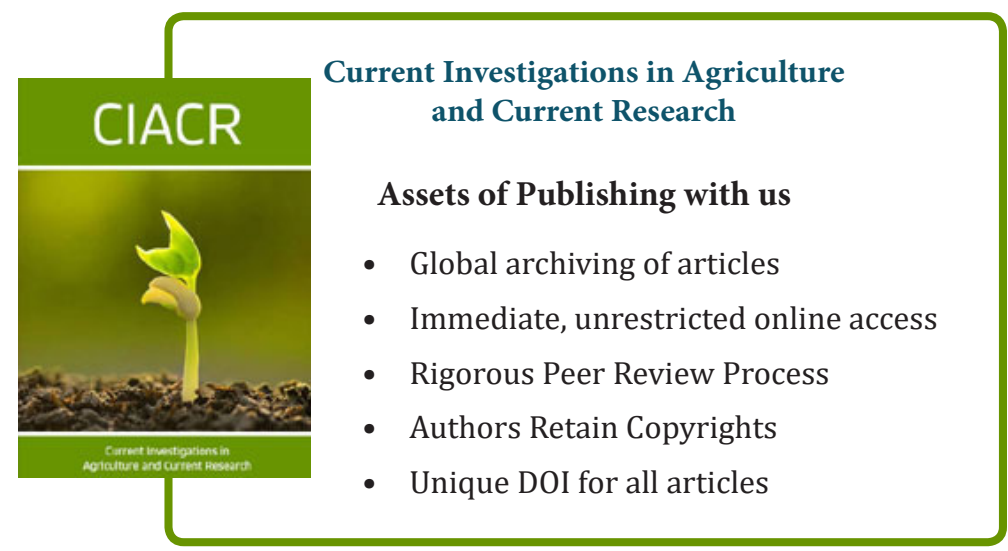

